\title{
SUCCESSION OF GROUND COVER VEGETATION IN HYLOCOMIOSA FOREST SITE TYPE AFTER THE CLEARCUT
}

\begin{abstract}
Edgars DUBROVSKIS, Latvia University of Agriculture, Faculty of Forestry, Department of Silviculture; 11 Akademijas street, Jelgava, LV-3001, Latvia; e-mail: edgars.dubrovskis@1lu.lv (corresponding author)

Aigars INDRIKSONS, Latvia University of Agriculture, Faculty of Forestry, Department of Silviculture; 11 Akademijas street, Jelgava, LV-3001, Latvia; e-mail: aigars.indriksons@1lu.lv

Olga MIEZĪTE, Latvia University of Agriculture, Faculty of Forestry, Department of Silviculture; 11 Akademijas street, Jelgava, LV3001, Latvia; e-mail: olga.miezite@1lu.lv

Lelde HERMANE, Latvia University of Agriculture, Faculty of Forestry; 11 Akademijas street, Jelgava, LV-3001, Latvia

Nowadays forestry sector uses forest site type descriptions developed from beginning of $20^{\text {th }}$ century till 1980's and descriptions are obtained for pre-mature and mature stand age. There is less information about ground cover vegetation for full rotation cycle. In this research has been gathered information about ground cover vegetation succession in first 5 years after clear cut in mature Scots pine stand. The chronosequence method was used. The Brown-Blanquet and the point-square methods for accounting of ground cover plants were used. The ecological values of Ellenberg for describing the environmental status and the coefficient of Tschekanovsky for estimation of the difference between plant communities in forest young growths of different age were used. The biological diversity of species in this research compared to mature stand also is increasing. Ellenberg's ecological indicator values as light and nitrogen are also increasing: nitrogen value has increased the most - by 2.62 units. There are registered changes in vascular plants, mosses, lichens and trees projective covering's proportion. The most significant changes in individual species occurrence are between the second and third year's (Tschekanovsky coefficient $=0.19$ ). Five years after clear cut the Tschekanovsky coefficient between the mature stand and five years old clearing is 0.18 . In the 4th and 5th year after the clear cut there increase the projective cover of Monocotyledonae plants (families Graminaea and Cyperaceae) forming higher vertical structure and overtaking the dominance from another groups. The results obtained in this research promote further research in different stand age.
\end{abstract}

Keywords: clear cut, forest site type, ground cover vegetation, rotation cycle, succession

\section{INTRODUCTION}

Forest site type merges similar growth conditions and describes how to recognize different growth conditions. Forest site type descriptions are obtained for age of pre-mature and mature forest stand (Bušs, 1981). However, till up to now, there is little knowledge about the ground cover vegetation succession during all the forest rotation cycle.

The forest typology in Latvia started in the beginning of 20th century when I. Gutorovičs for the first time forest site types defined in Latvian according to the specific growth conditions and the tree stand parameters (Sarma, 1954). In 1920 K. Melderis established base of forest types and during time several forestry experts (Kiršteins, 1926; Matīss, 1974; Bušs, 1976) upgraded forest type descriptions which included biological and silvicultural information for various forestry actions in forest. K. Bušs (1981) summarized forest typology information available in Latvia that forestry field is using even in nowadays. In Latvia is used complexed or eco systematic forest site type classification where description is consistently coordinated demands of forest biology, ecology and silviculture (Liepa et al, 2014).

The present research aim is to estimate ground cover succession in Hylocomiosa forest site type with Scots pine (Pinus sylvestris L.) as a dominant tree species. Pine is one of advisable tree species growing in this forest site type (Liepa et al, 2014). This forest type is called Pinetum hylocomiosum (Sarma, 1954) who is described as dry mineral soil forest site type with well-aerated medium fertile sandy loam, loamy and clay soil depending of soil parent material, geographical location and hydrological regime (Bušs, 1981).

\section{MATERIALS AND METHODS}

To clarify this scientific question was the chronosequence method used which assumes that different sites are similar except in age (Johnson \& Miyanishi, 2007), when the forest stands of the same forest site type and dominant tree 
species at different ages in different places are taken. For the beginning we took forest stands of the first 5 years after the clear cut. Six sample plots with size of $10 \mathrm{~m}^{2}$ per each forest stand (see Fig. 1) - clear cut were established in indicative - hillock, plain and decline places.

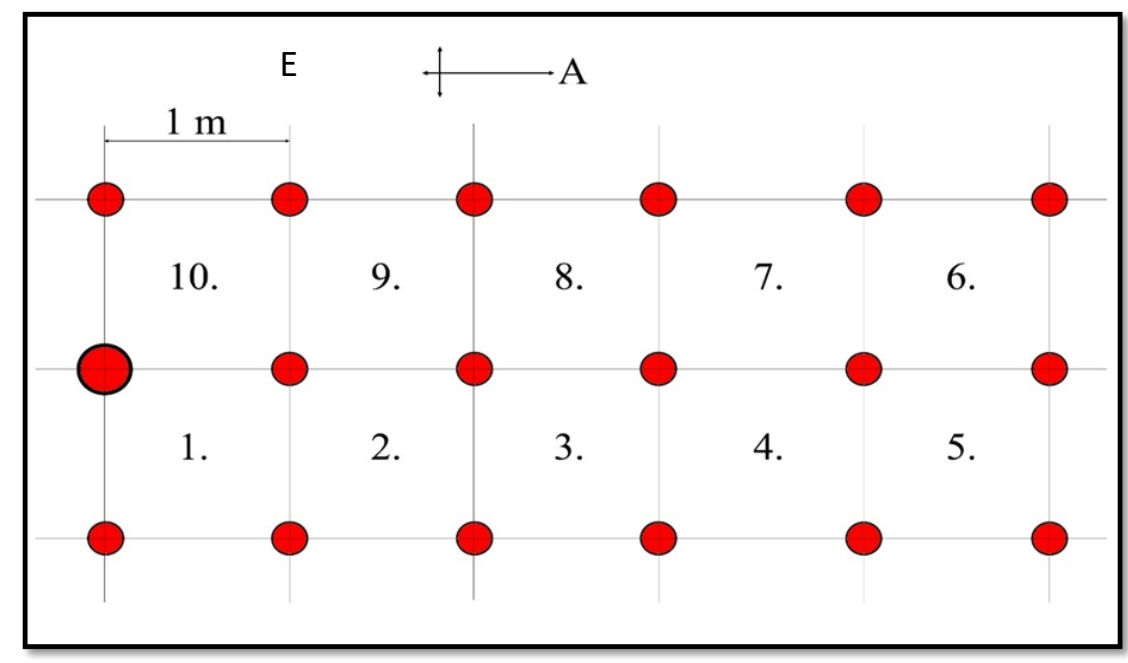

Figure 1. Sample plot structure scheme.

Both, the Brown-Blanquet (Wikum \& Shanholtzer, 1978) and the point-square methods by accounting of ground cover plants were used. Species with coverage of $2 \%$ or smaller are counted together in section "Other". Twenty sticks of $1 \mathrm{~mm}$ thick metallic needle were made in each square to estimate the taxonomic structure and abundance of plant species.

The ecological values of Ellenberg (Ellenberg, 2009) were used to describe the environmental status of each site. The coefficient of Tschekanovsky was used to estimate the difference between plant communities in forest young growths of different age. The forest site type investigated was the Hylocomiosa site type with Scots pine (Pinus sylvestris L.) as a dominant tree species. This forest site type is dominant in forests of Latvia, taking $20 \%$ of total forest area (State Forest Service, 2015).

\section{RESULTS AND DISCUSSION}

The results suggest considerable changes in taxonomic structure and abundance of ground cover plants in first years after the clear-cut (see Figure 2. - 4. ). Visual differences are visible in Fig. 2.

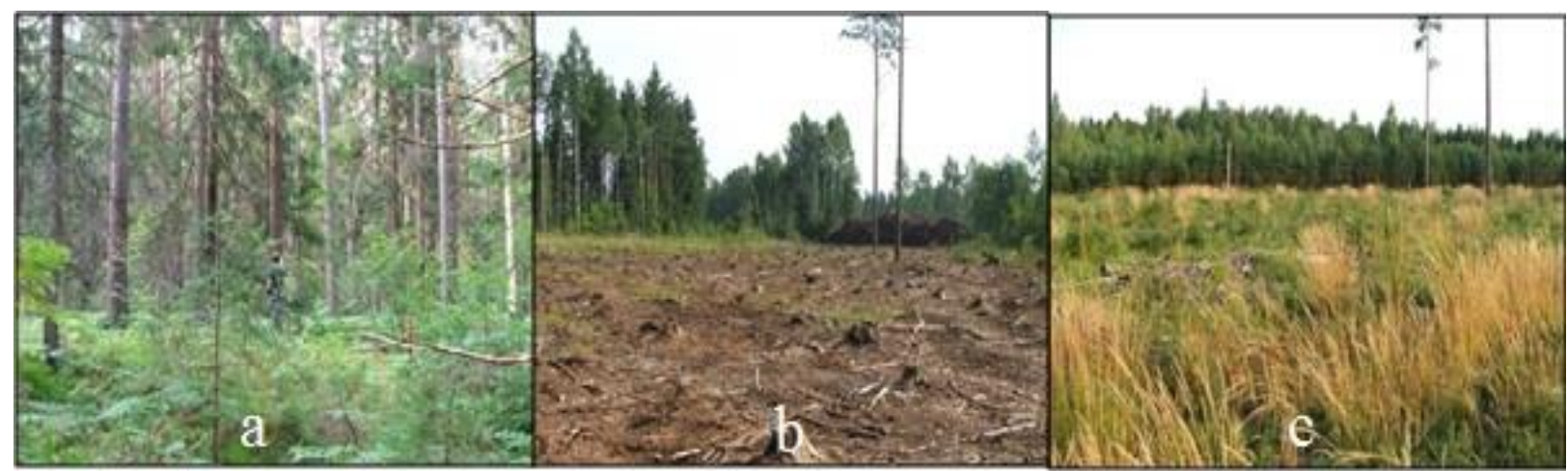

Figure 2. Pinetum hylocomiosum mature stand (a), 1 year old clear cut area (b) and 5 years old clear cut area (c).

During the first two years after the cutting the average height of ground cover plants reduces by $3.25 \mathrm{~cm}$. Later the height of ground cover vertical structure increases. In five years old clearing it is $8.25 \mathrm{~cm}$ bigger than in stand before cutting. There are registered changes in vascular plants, mosses, lichens and trees projective covering's proportion.

Moses in mature pine stand are most often encountering species (see Fig. 3). From all ground cover and regrowth species average one moss species projective coverage reaches $19.86 \%$. One tree and vascular plant species projective coverage is equal $-10.35 \%$ and $10.58 \%$ but comparatively small was lichen one species projective coverage.

During forest felling used heavy machinery decrease coverage of understory trees, shrubs and larger vascular plants but instead increases sun-loving plant, also moss and lichen coverage. Splendid feather moss (Hylocomium splendens Hedw.) one year after clear cut stays with largest projective covering (see Fig.4). Other Hylocomiosa forest site type ground cover plant species are observed but in different proportion comparing to mature pine stand. Projective coverage proportion after both registering methods increased to Red-stemmed feathermoss (Pleurozium schreberi Brind.Mitt.), Wood Cow- 
wheat (Melampyrum nemorosum L.) and Reed grass (Calamagrostis arundinacea L.) but using point-square method also notable projective coverage gained Pellucid four-tooth moss (Tetraphis pellucida Hedw.), Bilberry (Vaccinium myrtillus L.), Common wood sorrel (Oxalis acetosella L.), rare Spring-sedge (Carex ericetorum Pollich.), European goldenrod (Solidago virgaurea L.), sweet Vernal-grass (Anthoxanthum odoratum L.), Toothed plagiomnium moss (Plagiomnium cuspidatum Hedw.) and Cypress-leaved plait-moss (Hypnum cupressiforme Hedw.). Count of species with projective coverage under $2 \%$ decreased one year after clear cut was made.

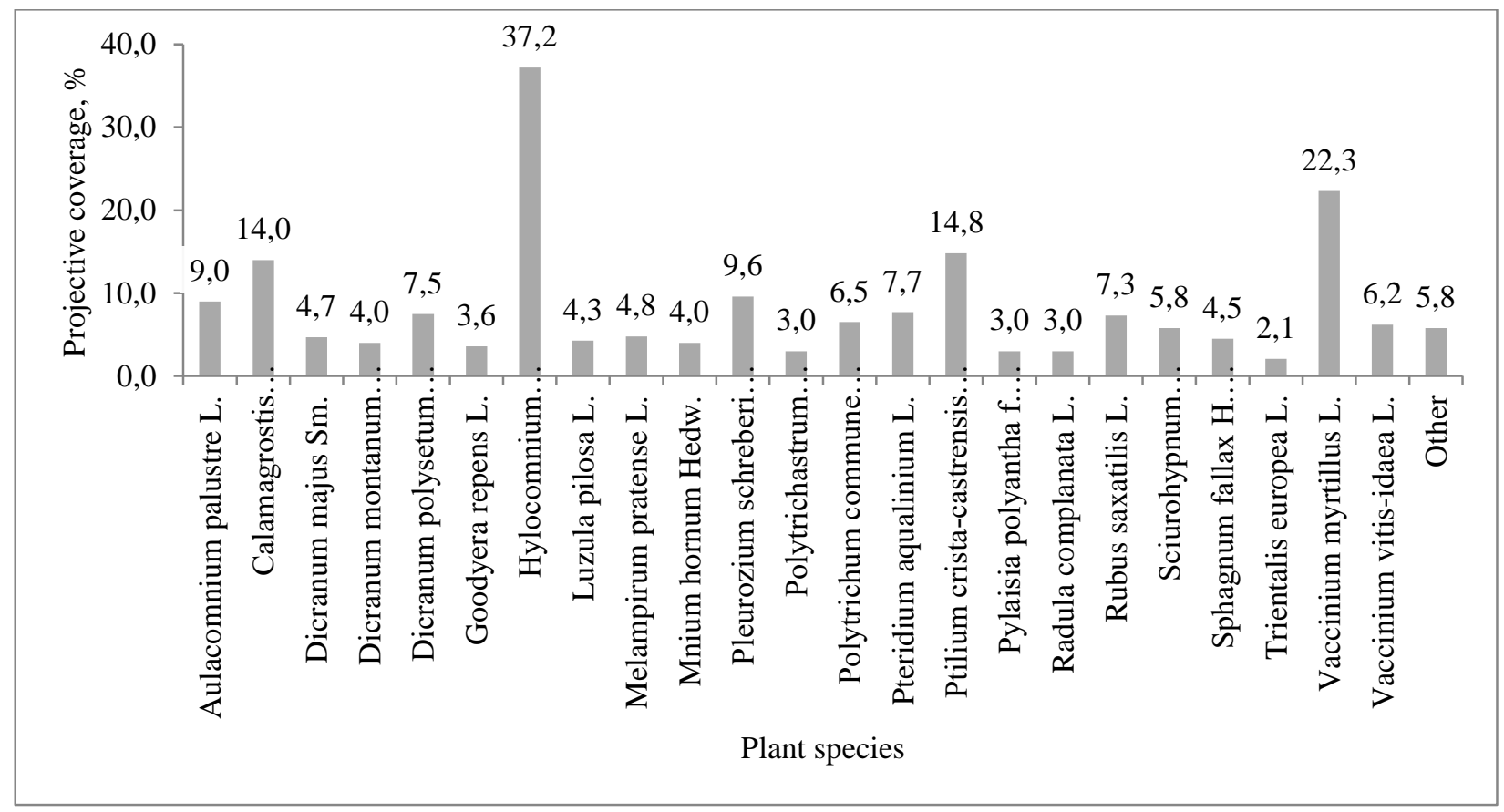

Figure 3. Projective cover of plants in mature Pinetum hylocomiosum forest stand before the cutting.

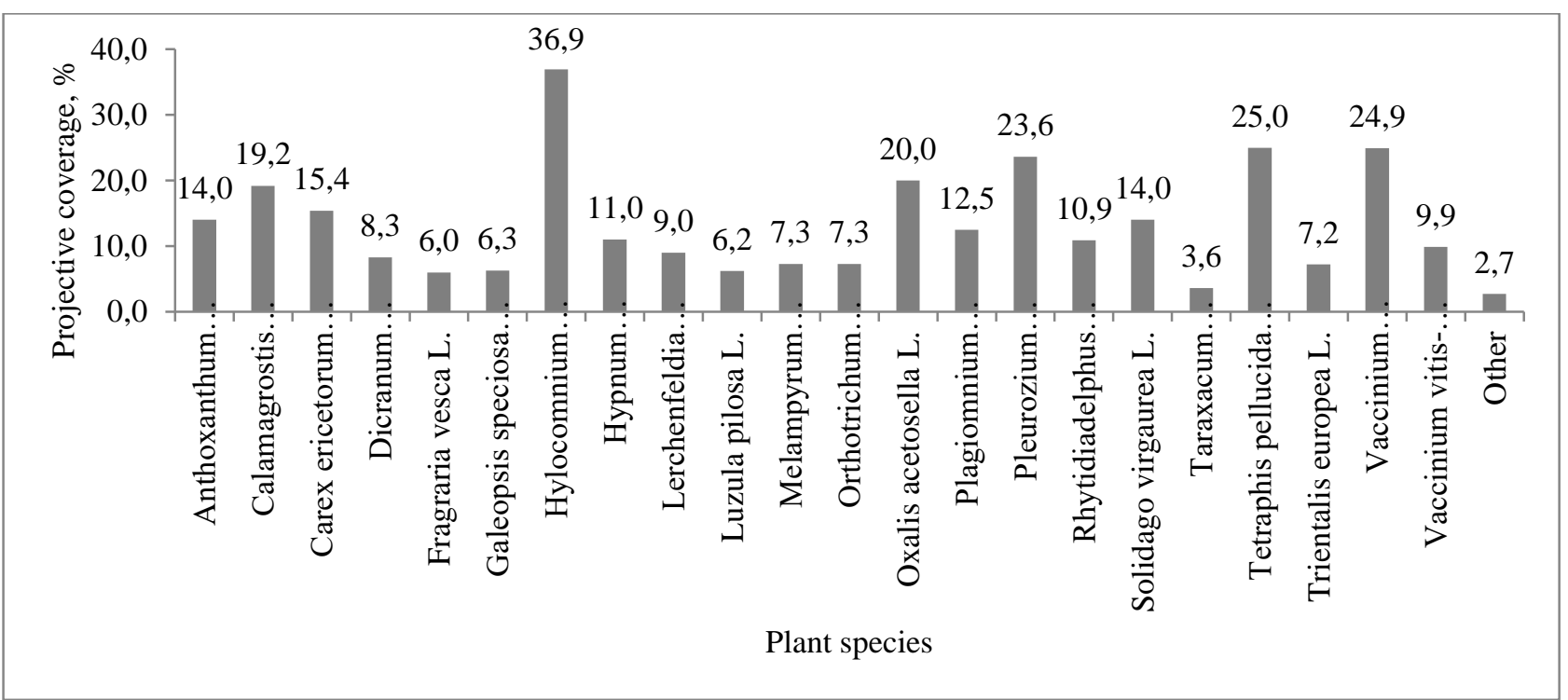

Figure 4. Projective cover of plants in a 1 year old pine Hylocomiosa clear-cut area.

Five years after clear cut species count has raised and raspberry (Rubus idaeus L.) has largest projective coverage but more than $10 \%$ projective coverage has sheep's sorrel (Rumex acetosella L.), large-flowered hemp-nettle (Galeopsis speciosa Mill.), oval sedge (Carex leporina L.) and also common cow-wheat (Melampyrum pratense L.), small tuftedsedge (Carex cespitosa L.), un hairy wood-rush (Luzula pilosa L.). As ground cover plants get taller, form larger groups (see Fig. 1c) and needle touching point also raises then increases average vertical height of registered vegetation. 


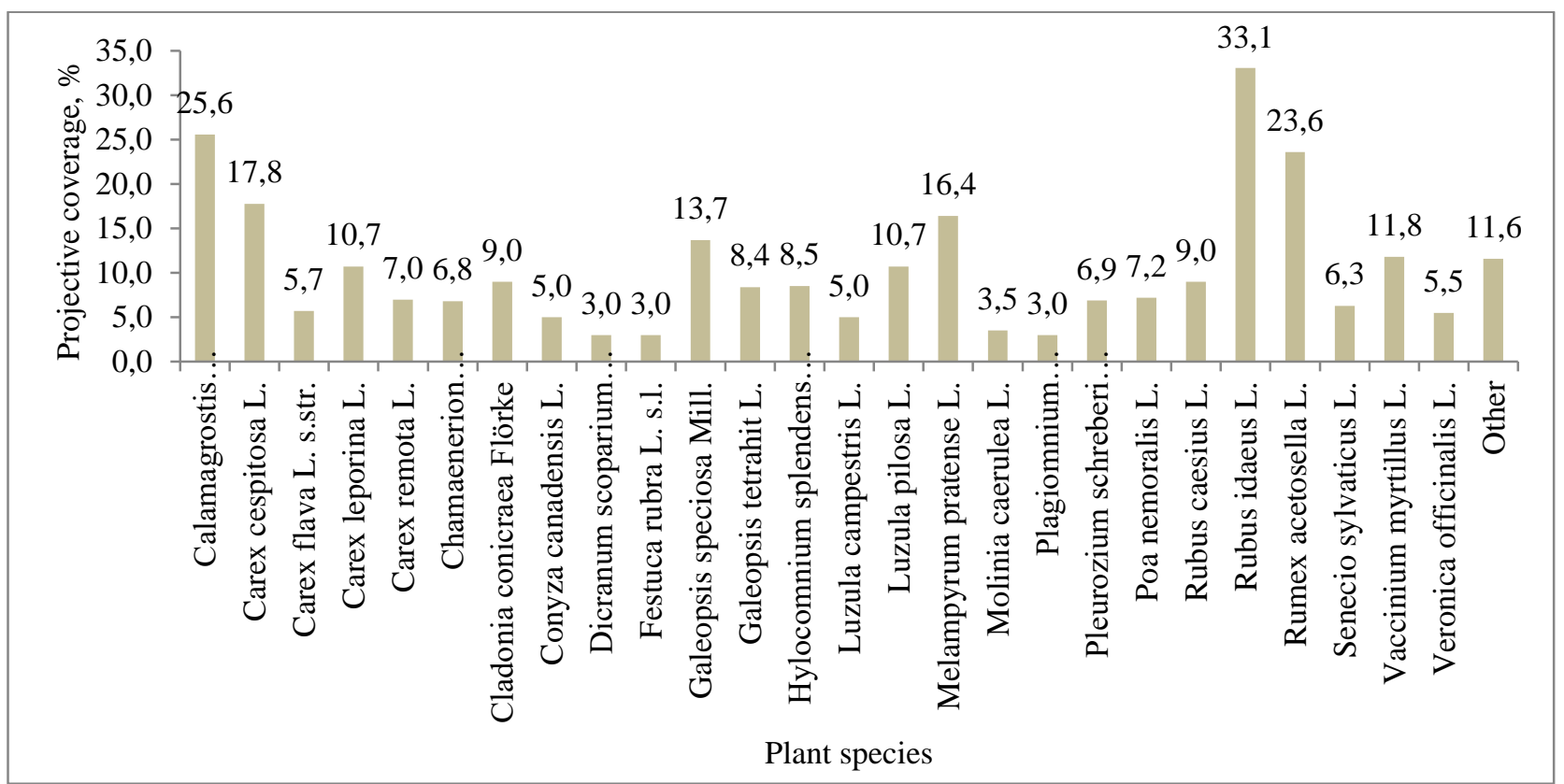

Figure 5. Projective cover of plants in a 5 years old pine Hylocomiosa clear-cut area.

Pykälä (2004) in South-West Finland established that the total and mean numbers of vascular plant species were almost double in clear-cut areas compared to mature forests. The biological diversity of species in this research compared to mature stand also is increasing: four species using point-square method and 17 species using Braun - Blanquet method appear as growth conditions improved and growth space increased. Shannon - Wiener index's values show that ground vegetation biological diversity has increased after the clear cut: $\mathrm{H}(\mathrm{s})$ in mature stand $=2,912$, but in five years old clearing $H(s)=3,202$. Ellenberg's ecological indicator values (Ellenberg, 1991) as light and nitrogen are also increasing: nitrogen value has increased the most - by 2,62 units (Fig. 6).

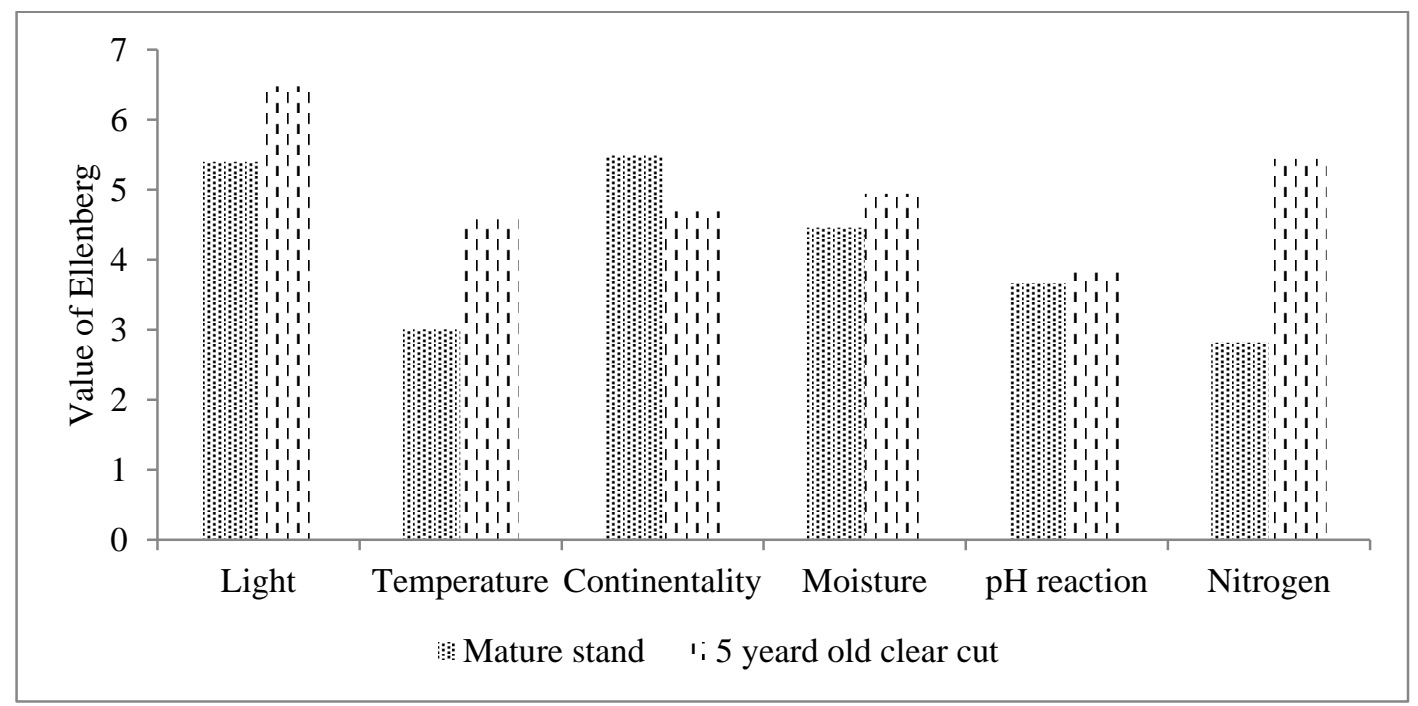

Figure 6. Ecological values of Ellenberg in a mature pine Hylocomiosa forest stand before and 5 years after the cutting.

The most significant changes in individual species occurrence are between the second and third year's and Tschekanovsky coefficient value $(0,19)$ is confirming that. Five years after clear cut ground vegetation has changed seriously: the Tschekanovsky's coefficient between the mature stand and five years old clearing is 0,18 .

\section{CONCLUSIONS}

After performing the clear cut there are significant changes in abundance of species of ground cover plants and in vertical structure of plant community. Till the second year after the cutting the total coverage of plants reduces. The most abundant are mosses. During the third year after clear cut there proceeds a rapid increase of weeds and decrease of mosses. The total species richness increases. In the 4th and 5th year after the clear cut there increase the projective cover of Monocotyledonae plants (families Graminaea and Cyperaceae) forming higher vertical structure and overtaking the dominance from another groups. The dominance of this group reduces by development of young tree stand. The results 
obtained and further research will be valuable supplement for practical forest inventory describing the characteristic ground cover vegetation in Hylocomiosa forest site type not only in mature forest age but during all forest rotation cycle.

\section{REFERENCES:}

1. Bušs, K. 1976. Latvijas PSR meža tipologijas pamati (Forest typology base of Latvian PSR). Rīga: LRZTIPI. [In Latvian]

2. Bušs, K. 1981. Meža ekoloǵija un tipoloǵija (Forest ecology and typology). Rīga, Zinātne. [In Latvian]

3. Ellenberg, H. H., Weber, E., Düll, R., Wirth, V., Werner, W., Paulißen. 1991. Indicator values of plants in Central Europe. Göttingen: Erich Goltze KG.

4. Ellenberg, H. H. 2009. Vegetation Ecology of Central Europe. 4th Edition. Cambridge: Cambridge University Press.

5. Johnson, E. A., Miyanishi, K. 2007. Plant disturbance ecology : the process and the response. Elsevier/AP.

6. Kiršteins, K. (1926) Tipologiiskās mežaudžu klasifikācijas izveidošanās un pielietošana praksē (Formation and practical usage of typological forest stand classification). Mežsaimniecības rakstu krājums, 4. sēj. 3-16. lpp. [In Latvian]

7. Liepa, I., Miezīte, O., Luguza, S., Šulcs, V., Straupe, I., Indriksons, A., Dubrovskis, D. 2014. Meža tipologija (Forest typology). Jelgava: Studentu biedrïba "Šalkone". [In Latvian]

8. Matīss, J. 1974. Meža taksācijas darbu vietējie noteikumi (Local rules of forest taxation work). Ref. krāj. Mežsaimniecība un mežrūpniecība. Nr. 3. 9. - 20. lpp. [In Latvian]

9. Pykälä, J. 2004. Immediate Increase in Plant Species Richness after Clear-Cutting of Boreal Herb-Rich Forests. Applied Vegetation Science, Vol. 7, Iss. 1, pp. 29-34. https://doi.org/10.1111/j.1654-109X.2004.tb00592.X

10. Sarma, P. 1954. Latvijas PSR meža tipi (Forest types of Latvian PSR). Rīga: Latvijas Valsts izdevniecība. [In Latvian]

11. State Forest Service. 2015. Meža statistika (Forest statistics). Available at http://www.vmd.gov.lv/valsts-meza-dienests/statiskaslapas/publikacijas-un-statistika/meza-statistikas-cd?nid=1809\#jump (Accessed on 21/08/2016) [In Latvian]

12. Wikum, D. A., Shanholtzer, G. F. 1978. Application of the Braun-Blanquet cover-abundance scale for vegetation analysis in land development studies. Environmental Management, Vol. 2(4), pp. 323-329. https://doi.org/10.1007/BF01866672 